\title{
Paraneoplastic limbic and extra-limbic encephalitis secondary to a thymoma mimicking an acute stroke
}

\author{
William Reginold, Kurian Ninan, Judith Coret-Simon, Ehsan Haider
}

Key Words: magnetic resonance imaging, paraneoplastic condition, thymoma

Paraneoplastic neurological syndromes (PNS) occur in one in ten thousand patients with malignancy. ${ }^{1}$ These syndromes are defined by dysfunction remote from the tumor site that cannot be explained by metastasis, treatment or infection. ${ }^{2}$ The dysfunction in PNS is believed to be a result of neoplastic immune-mediated injury to neural tissue. Antibodies may be created against proteins on cancer cells that are usually only expressed in the nervous system. Paraneoplastic neurological syndrome is thought to develop when these antibodies cross-react and trigger an autoimmune response in normal neural tissue. ${ }^{2}$ Presence of onconeural antibodies, clinical onset around the diagnosis of cancer and improvement with treatment of the cancer favors the diagnosis of PNS. Thymoma is a common anterior mediastinal malignancy. Approximately $40 \%$ of cases of thymoma are associated with PNS. ${ }^{3}$ The most common and well-known form of PNS in patients with thymoma is myasthenia gravis (MG). In MG the thymus can be the antigenic source for antibodies that disrupt neurotransmission. ${ }^{4}$ The most common antibodies found in MG are against the postsynaptic acetylcholine receptor or the muscle specific tyrosine kinase ${ }^{4}$ Around $15 \%$ of patients with a thymoma have a paraneoplastic process other than myasthenia gravis. ${ }^{3}$ Paraneoplastic involvement of the central nervous system is an uncommon and less recognized presentation of thymoma. We report a rare case of limbic and extra-limbic paraneoplastic encephalitis with a thymoma.

\section{Case Report}

A 47-year old male presented at the emergency room of a teaching tertiary care hospital with a two-day history of psychotic symptoms consisting of hallucinations, delusions, false memories and disorganized behavior. Patient had past medical history of fatigable weakness limited to the eyelids or extraocular muscles for six months and a brief psychotic episode 20 years earlier. On examination his oxygen saturation was $92 \%$ at room air (venous blood gas $\mathrm{pH} 7.4, \mathrm{pCO}_{2} 40 \mathrm{mmHg}, \mathrm{HCO}_{3} 25 \mathrm{mEq} / \mathrm{L}$ ). He had frontal release signs including positive involuntary grasp and a positive Luria's test. An unenhanced computed tomography (CT) brain scan was performed and demonstrated a left-sided $12 \mathrm{~mm}$ hypodense lesion in the frontal lobe (Figure 1a). This was interpreted as suspicious for an acute infarction. The patient was admitted to hospital under the Neurology service and had worsening psychotic symptoms. On day six, an unenhanced CT brain scan was repeated and demonstrated progression of the leftsided hypodense lesion that was interpreted as compatible with an evolving infarct (Figure 1b). Based on the results of this CT brain scan, a magnetic resonance imaging (MRI) scan of the brain was not immediately ordered.

On day 11, carotid Doppler and transthoracic echocardiography did not reveal any cardiovascular abnormality, but transthoracic echocardiography did demonstrate a large extracardiac mass. On day 14, contrast-enhanced CT of the thorax confirmed an $11 \times 10 \times 8 \mathrm{~cm}$ mediastinal mass lateral to the left border of the heart with soft tissue density and peripheral curvilinear calcifications (Figure 2). On day 21, CT guided biopsy of the mass determined it to be a thymoma. Contrast enhanced CT demonstrated no evidence of abdominal or pelvic metastasis or lymphadenopathy. Serum antibodies (anti-acetylcholine receptor, anti-muscle specific receptor tyrosine kinase, anti-low density lipoprotein receptor-related protein 4) associated with MG were not tested for.

During hospitalization the patient developed seizures and was started on phenytoin. Due to the new onset of seizures, on day 23 gadolinium-enhanced 1.5T MRI of the brain was performed and demonstrated multiple non-enhancing cortical lesions with high signal on T2 fluid attenuated inversion recovery (FLAIR) (Figure 3). There were no lesions identified in the limbic system. The largest lesion was located in the left frontal lobe and correlated with the hypodense lesion identified earlier by CT (Figure 1 and 3). The differential diagnosis for multifocal white matter hyperintensities includes infection, immune/inflammatory conditions, vasculitis, ischemia, metastasis, toxic-metabolic luekoencephalopathies, and age related changes. ${ }^{5}$ Since the lesions were also high signal on apparent diffusion coefficient (ADC), suggesting increased diffusion, the differential diagnosis was narrowed to include immune/inflammatory conditions, metastasis and older stroke lesions. ${ }^{6}$ (Figure 3). On cerebrospinal fluid analysis, protein $(0.22 \mathrm{~g} / \mathrm{L})$, glucose $(3.9 \mathrm{mmol} / \mathrm{L})$, leukocytes $\left(2 \times 10^{6} /\right.$ high powered field $)$ were within normal range. Cerebrospinal fluid bacterial cultures and polymerase chain reaction for

\footnotetext{
From the Department of Radiology, McMaster University, Hamilton, Ontario, Canada Received April 1, 2015. Final Revisions Submitted August 27, 2015. Correspondence to: Ehsan Haider, Faculty of Health Sciences, Department of Radiology, McMaster University, 50 Charlton Avenue East, Hamilton, Ontario, Canada, L8N 4A6. Email to: ehaider@st.joes.ca
} 


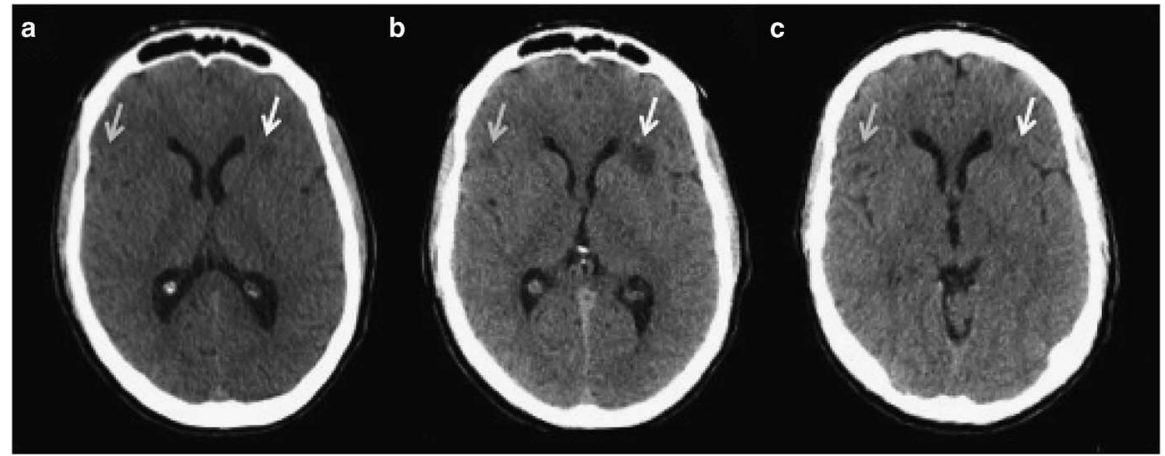

Figure 1: Progression of paraneoplastic extra-limbic encephalomyelitis on unenhanced CT brain. Axial images from CT brain demonstrating progression of two hypodense lesions identified by arrows at a) time of presentation; $b$ ) six days after presentation and; c) interval improvement after thymoma resection consistent with paraneoplastic encephalomyelitis.

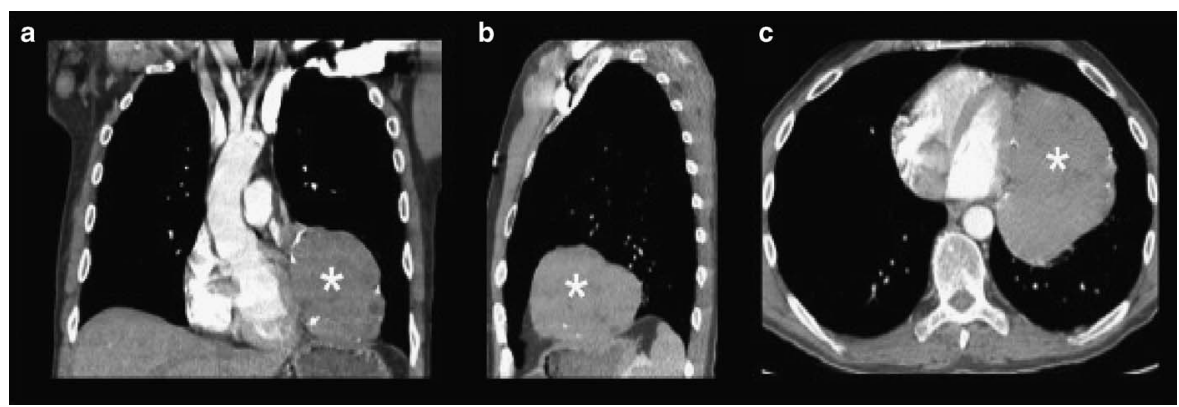

Figure 2: Anterior mediastinal mass on contrast enhanced CT of the thorax Anterior mediastinal mass with soft tissue density and peripheral curvilinear calcifications measuring $12 \times 11 \times 8 \mathrm{~cm}$ located lateral to the left ventricle identified by asterisk on a) coronal; b) sagittal and; c) axial images.

Herpes Simplex 1, Herpes Simplex 2, Varicella zoster and Enterovirus were negative. Immunoglobulin G index (0.4) was within normal range and oligoclonal bands were not detected. Cerebrospinal fluid cytology and flow cytometry was not performed. Paraneoplastic antibodies $\alpha-\mathrm{Hu}, \alpha$-Ri, $\alpha$-Yo were not detected in CSF.

Due to the suspicion of an immune/inflammatory condition the patient was started on dexamethasone but continued to have seizures and worsening encephalopathy. The thymoma was surgically excised. Final pathology revealed a $12 \mathrm{~cm}$ Modified Masaoka Stage 2A thymoma subtype B2 with negative margins, no lymphvascular or nodal invasion. Over the course of four weeks following the resection of the thymoma, the patient's seizures, psychotic symptoms, and ocular weakness resolved. Repeat CT brain demonstrated interval resolution of the hypodense lesions supporting the diagnosis of paraneoplastic encephalitis (Figure 1c).

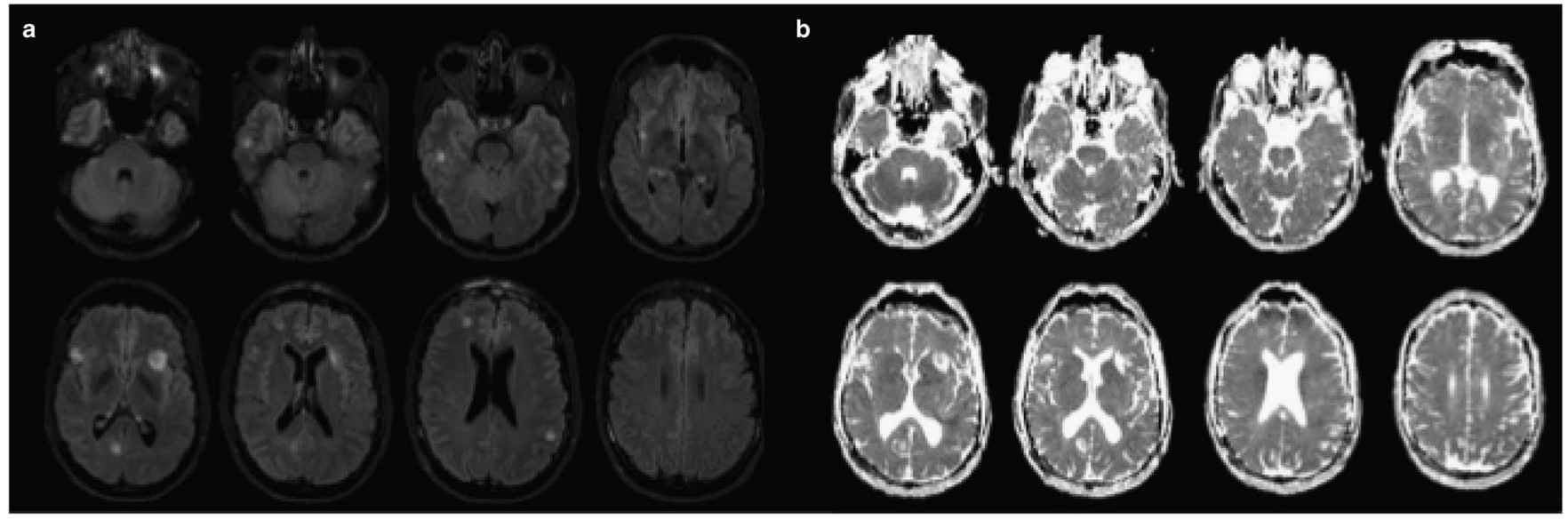

Figure 3: Paraneoplastic extra-limbic encephalomyelitis as high signal lesions on T2 FLAIR and ADC 1.5T MRI of the brain. a) Axial T2 FLAIR images from 1.5T MRI of the brain demonstrating several cortical high signal T2 FLAIR lesions located bilaterally in the frontal, parietal and temporal lobes; b) Axial ADC images demonstrating the cortical high signal lesions located bilaterally in the frontal, parietal and temporal lobes. 
Table 1: Summary of published cases with extra-limbic paraneoplastic encephalitis with thymoma

\begin{tabular}{|c|c|c|c|c|c|c|c|c|c|c|c|}
\hline Case & $\begin{array}{l}\text { Age, } \\
\text { Gender }\end{array}$ & Symptoms & Encephalitis & $\begin{array}{l}\text { MRI } \\
\text { Enhance- } \\
\text { ment }\end{array}$ & $\begin{array}{l}\text { Areas Involved on } \\
\text { MRI }\end{array}$ & Stage & CSF & Antibodies & Treatment & Outcome & $\begin{array}{l}\text { Abnormal initial MRI/ } \\
\text { Approximate number of } \\
\text { days after treatment when } \\
\text { improvement seen on MRI }\end{array}$ \\
\hline Our case & 47 , male & $\begin{array}{l}\text { Seizure, } \\
\text { memory } \\
\text { disruption, } \\
\text { psychosis }\end{array}$ & $\begin{array}{l}\text { Limbic }+ \\
\text { Extralimbic }\end{array}$ & None & $\begin{array}{l}\text { Bilateral frontal, } \\
\text { bilateral } \\
\text { temporal, right } \\
\text { occipital, left } \\
\text { insular }\end{array}$ & 2 & Normal & None & $\begin{array}{l}\text { Thymectomy, } \\
\text { corticosteroids }\end{array}$ & No residual symptoms & Yes/- \\
\hline $\begin{array}{l}\text { Rickman } \\
\text { et al. } \\
2000\end{array}$ & 55 , male & $\begin{array}{l}\text { Aphasia, ataxia, } \\
\text { gaze palsy, } \\
\text { seizures }\end{array}$ & $\begin{array}{l}\text { Limbic }+ \\
\text { Extralimbic }\end{array}$ & None & $\begin{array}{l}\text { Cerebral cortex and } \\
\text { limbic, not further } \\
\text { specified }\end{array}$ & $3^{*}$ & $\begin{array}{r}\text { Increased } \\
\text { protein }\end{array}$ & $\begin{array}{l}\text { Muscle acetylcholine } \\
\text { receptor binding } \\
\text { antibodies, acetylcholine } \\
\text { receptor modulating } \\
\text { antibodies, striational } \\
\text { antibodies, colapsin } \\
\text { response-mediator } \\
\text { protein antibodies. }\end{array}$ & $\begin{array}{l}\text { Partial thymectomy, } \\
\text { corticosteroids, } \\
\text { plasmaphoresis }\end{array}$ & Death $9 \mathrm{mo}$ & Yes/No improvement \\
\hline $\begin{array}{l}\text { Ances et al. } \\
2005\end{array}$ & 38 , male & $\begin{array}{l}\text { Seizure, } \\
\text { confusion, } \\
\text { memory loss }\end{array}$ & $\begin{array}{l}\text { Limbic }+ \\
\text { Extralimbic }\end{array}$ & None & $\begin{array}{l}\text { Right medial and } \\
\text { lateral temporal } \\
\text { lobe, right frontal, } \\
\text { left insular, left } \\
\text { occipital }\end{array}$ & 3 & $\begin{array}{l}\text { Increased } \\
\text { protein, } \\
\text { lymphocyte, } \\
\text { glucose }\end{array}$ & $\begin{array}{l}\text { Glutamic acid } \\
\text { decarboxylase antibody, } \\
\text { neuropil antibody }\end{array}$ & $\begin{array}{l}\text { Thymectomy, } \\
\text { corticosteroids, } \\
\text { IgG, } \\
\text { plasmaphoresis }\end{array}$ & $\begin{array}{l}\text { Short term memory } \\
\text { deficits, gait difficulty }\end{array}$ & Yes/150 \\
\hline $\begin{array}{c}\text { Okita et al. } \\
2007\end{array}$ & 34 , female & $\begin{array}{l}\text { Seizure, } \\
\text { confusion, } \\
\text { memory loss }\end{array}$ & $\begin{array}{l}\text { Limbic }+ \\
\text { Extralimbic }\end{array}$ & None & $\begin{array}{l}\text { Cerebral cortex and } \\
\text { limbic, not further } \\
\text { specified }\end{array}$ & 4 & Normal & $\begin{array}{l}\text { Binding acetylcholine } \\
\text { receptor, antinuclear } \\
\text { antibody }\end{array}$ & $\begin{array}{l}\text { Prior thymectomy } \\
\text { and radiation, } \\
\text { corticosteroids }\end{array}$ & No residual symptoms & Yes/70 \\
\hline $\begin{array}{l}\text { Hammoud } \\
\text { et al. } \\
2009\end{array}$ & 43 , female & $\begin{array}{l}\text { Seizure, } \\
\text { confusion, } \\
\text { aphasia }\end{array}$ & $\begin{array}{l}\text { Limbic }+ \\
\text { Extralimbic }\end{array}$ & Minimal & $\begin{array}{l}\text { Cerebral cortex and } \\
\text { limbic, not further } \\
\text { specified }\end{array}$ & 4 & $\begin{array}{l}\text { Increased } \\
\text { protein and } \\
\text { lymphocyte }\end{array}$ & $\begin{array}{l}\text { Acetylcholine receptor } \\
\text { binding antibodies, } \\
\text { acetylcholine receptor } \\
\text { modulating antibodies, } \\
\text { striational antibodies, } \\
\text { voltage gated potassium } \\
\text { channel antibodies } \\
\text { (LGI1) }\end{array}$ & $\begin{array}{l}\text { Prior thymectomy, } \\
\text { corticosteroids, } \\
\text { IgG, radiation, } \\
\text { chemotherapy }\end{array}$ & Death $2 \mathrm{mo}$ & Yes/no repeat MRI \\
\hline $\begin{array}{l}\text { Erkmen } \\
\text { et al. } \\
2011\end{array}$ & 61 , female & $\begin{array}{l}\text { Seizure, } \\
\text { memory } \\
\text { deficit }\end{array}$ & $\begin{array}{l}\text { Limbic }+ \\
\text { Extralimbic }\end{array}$ & None & $\begin{array}{l}\text { Cerebral cortex and } \\
\text { limbic, not further } \\
\text { specified }\end{array}$ & 3 & $\begin{array}{l}\text { Increased } \\
\text { lymphocyte }\end{array}$ & $\begin{array}{l}\text { Voltage gated potassium } \\
\text { channel antibodies } \\
\text { (LGI1) }\end{array}$ & $\begin{array}{l}\text { Thymectomy, } \\
\text { radiation, } \\
\text { corticosteroids, } \\
\text { IgG }\end{array}$ & No residual symptoms & Yes/28 \\
\hline $\begin{array}{l}\text { Suh et al. } \\
2013\end{array}$ & 42 , female & $\begin{array}{l}\text { Confusion, } \\
\text { memory loss }\end{array}$ & $\begin{array}{l}\text { Limbic }+ \\
\text { Extralimbic }\end{array}$ & $\mathrm{n} / \mathrm{a}$ & $\begin{array}{l}\text { Cerebral cortex and } \\
\text { limbic, not further } \\
\text { specified }\end{array}$ & 4 & $\mathrm{n} / \mathrm{a}$ & None & Thymectomy & No residual symptoms & Yes/96 \\
\hline $\begin{array}{l}\text { Vernino } \\
\text { et al. } \\
2004\end{array}$ & 34 , female & $\begin{array}{l}\text { Seizure, } \\
\text { neuropathy, } \\
\text { vertigo }\end{array}$ & Extralimbic & None & $\begin{array}{l}\text { Bilateral insula, left } \\
\text { temporal, right } \\
\text { occipital, left } \\
\text { medial frontal. }\end{array}$ & 1 & $\begin{array}{r}\text { Increased } \\
\text { protein }\end{array}$ & Anti-Hu antibody & Thymectomy & Residual pupil weakness & $\mathrm{No} / 42$ \\
\hline $\begin{array}{l}\text { Rizzardi } \\
\text { et al. } \\
2009\end{array}$ & 55, male & Seizure, aphasia & Extralimbic & $\mathrm{n} / \mathrm{a}$ & $\begin{array}{l}\text { Insular, parietal and } \\
\text { temporal lobe }\end{array}$ & 2 & Normal & None & $\begin{array}{c}\text { Thymectomy, } \\
\text { radiation }\end{array}$ & No residual symptoms & Yes $/ 30$ \\
\hline $\begin{array}{l}\text { Werry et al. } \\
2009\end{array}$ & 32 , male & $\begin{array}{l}\text { Seizure, ataxia, } \\
\text { vertigo, } \\
\text { nystagmus }\end{array}$ & Extralimbic & None & $\begin{array}{l}\text { Insula bilateral, } \\
\text { medial right } \\
\text { temporal lobe, } \\
\text { left } \\
\text { pariteooccipital } \\
\text { lobe }\end{array}$ & 1 & $\begin{array}{l}\text { Increased } \\
\text { lymphocyte }\end{array}$ & $\begin{array}{l}\text { Colapsin response- } \\
\text { mediator protein } \\
\text { (CRMP5) antibodies }\end{array}$ & $\begin{array}{l}\text { Thymectomy, } \\
\text { corticosteroids, } \\
\text { IgG, radiation, } \\
\text { chemotherapy }\end{array}$ & $\begin{array}{l}\text { Headache, fatigue, } \\
\text { myasthenic ptosis }\end{array}$ & $\mathrm{No} / 14$ \\
\hline $\begin{array}{l}\text { Aysal et al. } \\
2013\end{array}$ & 43 , male & Seizure & Extralimbic & None & $\begin{array}{l}\text { Left } \\
\text { temporoparietal, } \\
\text { left insular cortex, } \\
\text { left frontal } \\
\text { subcortical, right } \\
\text { hippocampus }\end{array}$ & $2^{*}$ & Normal & None & Thymectomy, IgG. & Weakness on blinking & Yes/50 \\
\hline
\end{tabular}

Stage is based on the thymoma Masaoka staging system. Asterix represent presumed stage based on case description. 
Since the clinical presentation was consistent with limbic involvement (psychotic symptoms, behavioral changes and seizures) and the CT and MRI studies demonstrated extralimbic involvement, this case was classified as limbic and extralimbic paraneoplastic encephalitis. Repeat MRI brain was not performed.

\section{Discussion}

This case demonstrates a rare paraneoplastic syndrome affecting the cerebral cortex. The hallmark feature of the PNS in this case is the temporal association of neurological symptoms with the diagnosis and treatment of the thymoma. It is highly unlikely for infection or metastasis to spontaneously remit and even less likely for either to do so in synchrony with cancer treatment. According to diagnostic criteria for definite PNS, a classical neurological syndrome must develop within five years of the diagnosis of cancer and the presence of onconeural antibodies is not required. Encephalitis is considered a classical neurological syndrome. Therefore, even though a paraneoplastic antibody was not positively identified, this case meets diagnostic criteria for definite PNS ${ }^{1}$ Ten cases of paraneoplastic encephalitis extending beyond the limbic system have been described in association with a thymoma (Table 1). ${ }^{3,7-15}$ Of these cases only four exclusively involved the extra-limbic system. ${ }^{3,7-9}$

Similar to all other cases of limbic and extralimbic paraneoplastic encephalitis with a thymoma our patient had confusion, memory disruption, seizures, and non-enhancing bilateral lesions on MRI (Table 1). In 30\% of cases, the patient was known to have a thymoma prior to any brain imaging. This was usually picked up as a mediastinal mass on chest x-ray. In cases of extra-limbic paraneoplastic encephalitis, only $70 \%$ had antibodies or elevated protein, lymphocytes or glucose on CSF. This highlights that extra-limbic paraneoplastic encephalitis can occur without the onconeural antibodies or signs of inflammation in the CSF. However, we cannot conclude that our case is without onconeural antibodies. A limitation of our case was that only a few onconeural antibodies were tested for (anti-Hu, anti-Ri, anti-Yo). In paraneoplastic limbic encephalitis there have also been associations with onconeural antibodies against CV2/CRMP5, Ma2, NMDA receptor, AMPA receptor, GABA $\beta$ receptor, LGI1 and CASPR2 proteins [reviewed in 16]. Antibodies against LGI1, AMPA receptor and CV2/CRMP5 have been previously related to limbic encephalitis with a thymoma. ${ }^{16}$ Antibodies can play an important role in the diagnosis of PNS. According to diagnostic criteria, in the absence of cancer, onconeural antibodies can be used to classify a classical neurological condition as definite PNS. ${ }^{1}$ Also, in the presence of cancer, onconeural antibodies can be used to classify a non-classical neurological condition as definite PNS. ${ }^{1}$ In patients with suspected PNS we recommend further antibody testing to aid in diagnosis.

Similar to an infarct, paraneoplastic encephalitis can appear as a prominent, progressively enlarging hypodense lesion on unenhanced CT brain. The presence of several discrete lesions is more suggestive of paraneoplastic encephalitis. In our case, MRI identified several lesions with high signal on both T2 FLAIR and ADC that were not detectable by CT. Brain MRI does not always demonstrate abnormalities in symptomatic patients with extralimbic paraneoplastic encephalitis. In two published cases there was a normal initial brain MRI (Table 1). ${ }^{3,4}$ In both cases abnormalities were identified on repeat MRI one to three months after the onset of symptoms. Therefore, a normal MRI does not exclude paraneoplastic encephalitis. Abnormalities on MRI in extra-limbic paraneoplastic encephalitis include bilateral nonenhancing hyperintense lesions on T2 FLAIR and ADC. The insula, temporal lobe and frontal lobe were commonly affected extralimbic sites.

Eighteen percent of patients with extralimbic paraneoplastic died as a consequence of the thymoma. Early recognition of paraneoplastic encephalitis may lead to earlier diagnosis and treatment of the thymoma. Patients can have complete resolution of symptoms with thymectomy and immunomodulatory therapy. This highlights the importance of early diagnosis. The presence of a mediastinal mass in a patient with acute change in mental status should raise suspicion for paraneoplastic encephalitis from a thymoma.

\section{Disclosures}

William Reginold, Kurian Ninan, Judith Coret-Simon, and Ehsan Haider have nothing to disclose.

\section{REFERENCES}

1. Graus F, Delattre JY, Antoine JC, et al. Recommended diagnostic criteria for paraneoplastic neurological syndromes. J Neurol Neurosurg Psychiatry. 2004;75:1135-40.

2. Didelot A, Honnorat J. Paraneoplastic disorders of the central and peripheral nervous systems. Handb Clin Neurol. 2014;121: 1159-79.

3. Aysal F, Baybas S, Selçuk HH, et al. Paraneoplastic extralimbic encephalitis associated with thymoma and myastenia gravis: three years follow up. Clin Neurol Neurosurg. 2013;115:628-31.

4. Spillane J, Higham E, Kullmann DM. Myasthenia gravis. BMJ. 2012;345:e8497.

5. Weidauer S, Nichtweiss M, Hattingen E. Differential diagnosis of white matter lesions: Nonvascular causes-Part II. Clin Neuroradiol. 2014;24:93-110.

6. Stadnik TW, Demaerel P, Luypaert RR. Imaging tutorial: differential diagnosis of bright lesions on diffusion-weighted MR images. Radiographics. 2003;23:e7.

7. Werry C, Götz F, Wurster U, et al. Paraneoplastic autoimmune encephalitis associated with CV2/CRMP-5 IgG antineuronal antibodies in a patient with thymoma. J Neurol. 2009;256: 129-31.

8. Hammoud K, Kandimala G, Warnack W, et al. Multifocal paraneoplastic cortical encephalitis associated with myasthenia gravis and thymoma. Arch Neurol. 2009;66:1407-9.

9. Vernino S, Eggenberger ER, Rogers LR, et al. Paraneoplastic neurological autoimmunity associated with ANNA-1 autoantibody and thymoma. Neurology. 2002;59:929-32.

10. Rickman OB, Parisi JE, Yu Z, et al. Fulminant autoimmune cortical encephalitis associated with thymoma treated with plasma exchange. Mayo Clin Proc. 2000;75:1321-6.

11. Ances BM, Vitaliani R, Taylor RA, et al. Treatment-responsive limbic encephalitis identified by neuropil antibodies: MRI and PET correlates. Brain. 2005;128:1764-77.

12. Okita K, Matsukawa N, Hattori M, et al. Recurrent limbic and extralimbic encephalitis associated with thymoma. Clin Neurol Neurosurg. 2007;109:206-9.

13. Erkmen CP, Fadul CE, Dalmau J, et al. Thymoma-associated paraneoplastic encephalitis (TAPE): diagnosis and treatment of a potentially fatal condition. J Thorac Cardiovasc Surg. 2011;141: e17-20.

14. Suh JW, Haam SJ, Song SW, et al. Paraneoplastic encephalitis associated with thymoma: a case report. Korean $\mathbf{J}$ Thorac Cardiovasc Surg. 2013;46:234-6.

15. Rizzardi G, Campione A, Scanagatta P, et al. Paraneoplastic extra limbic encephalitis associated with thymoma. Interact Cardiovasc Thorac Surg. 2009;9:755-6. 